\title{
The Growth of Sea cucumber Stichopus herrmanni After Transverse Induced Fission in Two and Three Fission Plane
}

\author{
Retno Hartati*, Widianingsih, Hadi Endrawati \\ Marine Science Department, Faculty of Fisheries and Marine Science, Diponegoro University \\ Jl. Prof. Soedarto, SH, Kampus Tembalang, Semarang \\ Email: retnohartati.undip@yahoo.com
}

\begin{abstract}
Transverse induced fission proven could be done in Teripang Tril, Stichopus herrmanni. This present works aimed to analyze wound recovery, regeneration period and growth of Teripang Trill after asexual reproduction by fission using two and three fission plane. Observations were made every day until the sea cucumber body separated into two or more (depending on treatment) and reared for 16 weeks. The results showed that there are differences in wound recovery, regeneration period and growth of S. herrmanni depend on their different fission plane. The wound recovery and regeneration period (days) of anterior, middle and posterior individu S. herrmanni resulted from two and three fission plane were varied but the two fission plane the anterior individu recover for longer period than posterior part and the wound recover process in both end for thee fission plane was same. Average growth of anterior and posterior fragment were longer for two fission plane than three fission plane. The middle fragment (M1 and M2) both fission plane was able to grow but very low. It showed that three fission plane gave very slow growth in every fragment of the body.
\end{abstract}

Keywords: growth, post-fission, fission plane, Stichopus herrmanni

\section{Introduction}

The ability to regenerate among Holothuroidea occur after the phenomenon of eviseration as a defend mechanism and after fission in asexual reproduction. Many marine organisms have ability to reproduce asexually (Gouyon et al., 1993). Natural asexual reproduction in the sea cucumber has been observed in the order of Dendrochirotida and Aspidochirotida, and has been known to be happen in 10 species of sea cucumber from tropical waters (Conand et al., 1997; Conand et al., 1998; Kohtsuka et al., 2005). The sea cucumber with ability to reproduce asexually by fission naturally are included as fissiparous holothuria. In asexual reproduction, sea cucumbers do divide its body or fission. After fission, anterior part of body complete with mouth and tentacles and some internal organs will regenerate and grow as well as the posterior part with anus, some intestinal and respiratory tree, become a new individual.

Fission on fissiparous species can occur naturally in the laboratory, especially when rearing is done in the period of asexual reproduction season. For example Stichopus chloronotus were narrowed on her wall in their habitat, immediately transferred to the laboratory to observe the process of fission (Uthicke, 2001) . However the desirable is the cleavage of sea cucumbers that can be controlled so that fission can occur in both species in the category fissiparous and non fissiparous. And it has been proven by Hartati et al., (2009) in nine holothurian species from Karimunjawa Waters, Jepara.

The measurement of body weight during recovery and change in morphology of individus resulted from fisson inducement has been conducted upon $H$. atra by Purwati and Dwiono (2007). Hartati et al. (2013) oberserved induced fission of two Stichopudidae species i.e. Stichopus herrmanni and S. chloronotus. They reported the species's entire process of fission, closed of the wounds and signs of short time regeneration but none has been done to determine further individual growth after induced fission of S. hermanni. The objective of present work was to measure individus growth after induced fission with two and three fission plane of transversed induced fission in $\mathrm{S}$. hermannii..

\section{Materials and Method}

Transversed induced fission was carried out on 30 individus of $S$. hermannii collected from Karimunjawa Waters, Jepara (average body weight 350 g.). Prior to fission inducement sea cucumber 
were kept in bottom seacage culture system sized of $5 \times 5 \times 3 \mathrm{~m}^{3}$. Bottom of cage was sandy-mud substrate planted with seagrass of Thallasia, Cymodocea, Enhallus taken from surrounding cage. The seaweed of Padina were also put into the cage providing additional feed for sea cucumber others than microphyto-zoobenthic from the substrate.

The experiment was started in the afternoon when the day has already cool to reduce sea cucumber stress. Fission stimulation was conducted in 5 Itrs tray filled with seawater. Transverse fission was induced by placing rubber bicycle inner tubes around the body of sea cucumbers depending the treatment of experiment. The treatment was two and three fission plane, in which 15 sea cucumber were tied in two and three places respectively (Fig. 1). This treatment was modified by Hartati et al. (2009) from the methods of Purwati dan Dwiono (2005; 2007). After being tied for fission, the sea cucumber were placed in plastic perforated basket sized of $20 \times 40 \times 10 \mathrm{~cm}^{3}$ covered with nets to protect the animals from predators. Stocking density of the sea cucumber was two individus per baskets. Baskets then was placed hang in the bamboo pool in the cage just under the surface of the seawater. When fission occured and wound recover, the sea cucumber were still kept in the basket and no food was added. This treatment continued untuk morphological recovery was completed. When a new anal or mouth aperture started to appear, the animals were moved in the cage. There is no treatment in the cage as food has already available in the substrate in the cage bottom.

Observation of the sea cucumber was perfomed on every individual sea cucumber during and after fission. After sea cucumber underwent fission and the wound was cured. The growth or regeneration of body part individu resulted from fission was measured for total growth to the nearest $1 \mathrm{~mm}$, measured dorsally from constriction point to end of animal by means of flexible ruler. The new individus resulted from two fission plane were anterior $(A)$, middle $1(M 1)$ and posterior $(P)$ parts of the body while three fission plane will divide the sea cucumber become four parts of body, i.e. anterior $(\mathrm{A})$, middle $1(\mathrm{M} 1)$, middle $2(\mathrm{M} 2)$, and posterior $(\mathrm{P})$. The growth of anterior part was in the posterior end of the new individu and the growth of posterior part was in the anterior end of the new individu. The growth of middle part in two fission plane (Middle 1) were in the anterior end (Anterior Middle 1, AM1) and posterior end (Posterior Middle 1, PM1) of new individu. While the growth of middle part in three fission plane (Middle 1 and Middle 2) were in the anterior end (Anterior Middle 1, AM1) and posterior end (Posterior Middle 1, PM1) of new individu of Middle 1 as well as in the anterior end (Anterior Middle 2, AM2) and posterior end (Posterior Middle 2, PM1) of new individu of Middle 2. (see schematic Figure 3). The measurement of body part of individus growth was carried out biweekly for sixteen weeks.

\section{Results and Discussion}

Unlike sexual reproduction which is universal, asexual reproduction of fissiparous species may not occur in certain habitats. Naturally, fission area tends to be specific. Each species may need particular requirement of triggers, including failure of sexual recruitment. Active fission effects individual size of the populations while the population density remains stable.

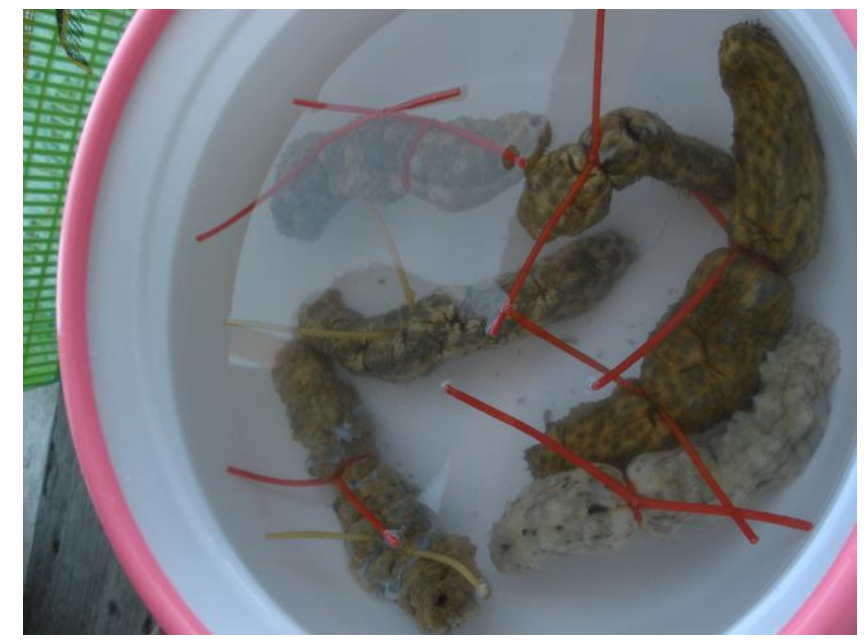

Figure 1. Transverse induced fission with rubber bicycle inner tubes of S. hermannii on two and three fission planes 


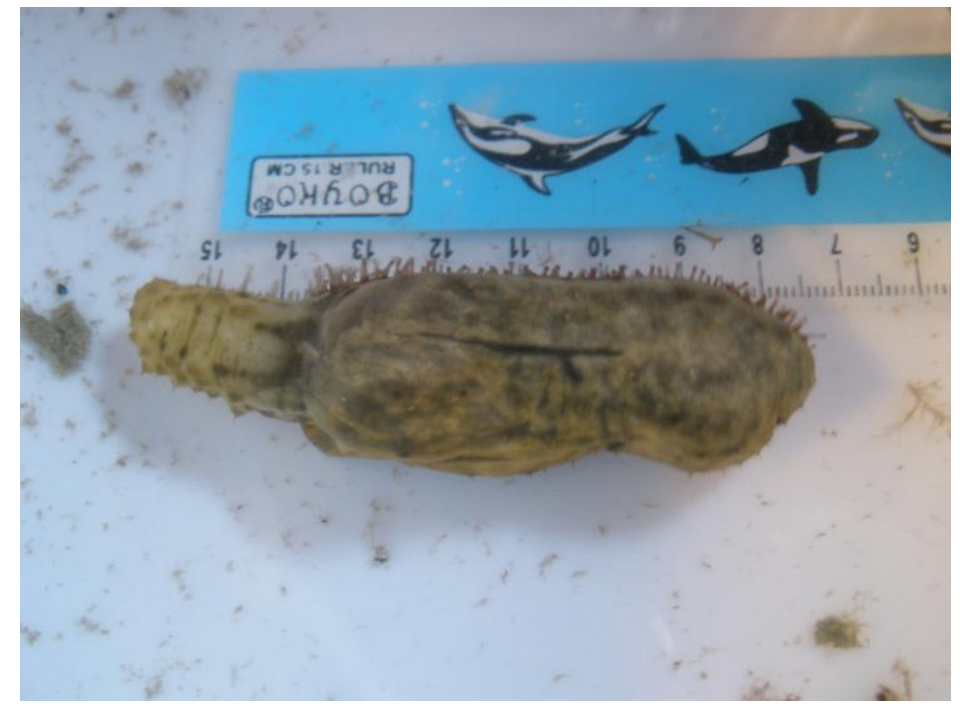

Figure 2. The measurement of regeneration and growth of individu after fission
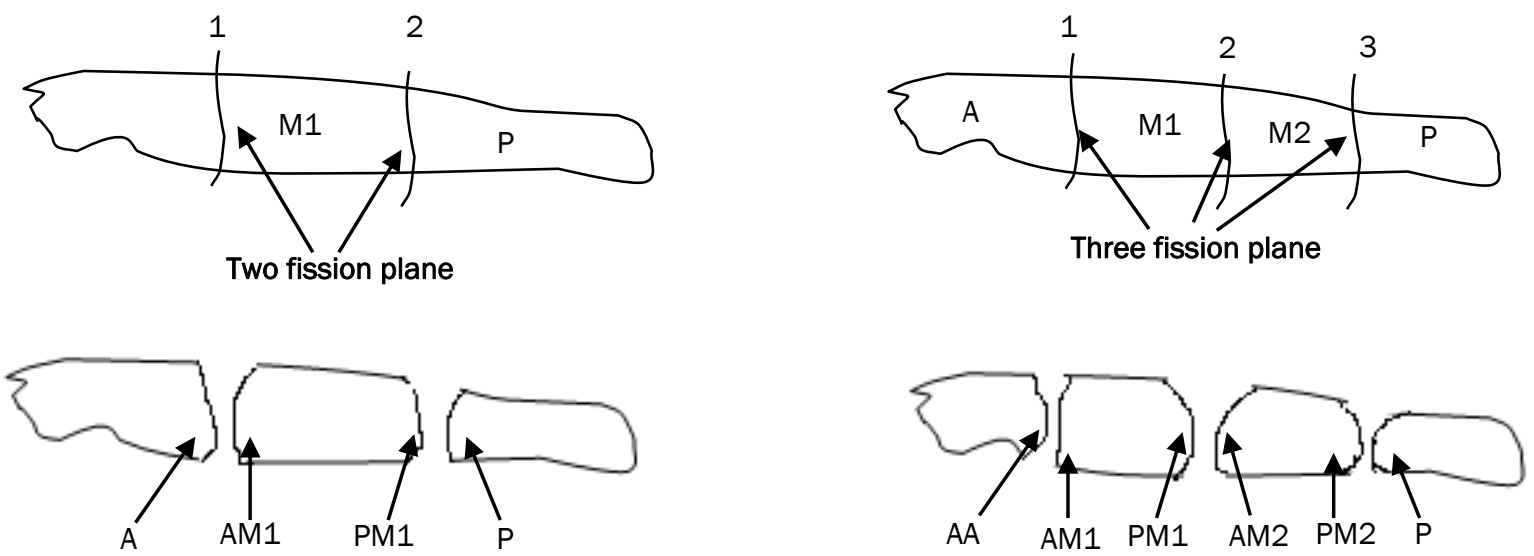

Figure 3. The schematic growth position of individu after fission of two and three fission plane Note : A=Anterior; M1=Middle1; AM1=Anterior Middle1; PM1=Posterior Middle1; M2=Middle2; AM2=Anterior Middle2; PM2=Posterior Middle; $\mathrm{P}=$ Posterior

Fission stimulation, in which holothurians are induced to divide, has prosperous potential for seed production. This technique has proven successfull for both fissiparous and non-fissiparous holothurians as has been carried out by works of Reichenbach et al. (1996), Laxminarayana (2006), Purwati and Dwiono (2007), Razek et al. (2007), Hartati et al. (2009; 2013; 2015a; b), Hermawan et al. (2012), (Nugroho et al. (2012), Karim et al. (2013); and Muttaqin et al. (2013).

The present work did induced transerved fisiion S. herrmanni in two and three fission plane. Observations showed that the body was more constricted at the constriction point of fission plane. The posterior part was swollen and extended. The anterior, middle, and posterior parts was not rotated in opposite directions until that parts stretched like happened in natural fission. Naturally most holothurian species with asexual reproduction follow the twisting and stretching mode (Uthicke, 2001). Instead, in this present work, the mechanical properties of the body wall allow this organ to become semi-fluid, and the sections may separate rapidly, apparently with minor effort simply by forward movement of the anterior, as had happened in S. chloronotus (Uthicke, 2001). It was noted that in this experiment none individuals eviscerated at the constriction point as happened in induced fission of $H$. aerenicola (Razek et al., 2007). After one day, the anterior and posterior parts were completely separated. According to Dulmatov 
(2014), the difference in fission duration between various fissiparous species is most likely determined by differences in extracellular matrix properties and matrix metallo proteinases, tissue inhibitors of metalloproteinases, and other enzymatic activities. The entire process of fission lasted from one to five days.

Tabel 1 shows time needed for sea cucumber to recover the wound in the constriction site or fisson plane. It shows that the two fission plane the anterior individu recover for longer period than posterior part but the wound recover process in both end for thee fission plane was same (average of 68 days). All of middle wound part (M1 and M2) recover for longer period of time than anterior $(A)$ and posterior (P). Razek et al. (2007) found that temperature had a considerable effect on the fission process. The dividing rate was greater at high temperatures $\left(30^{\circ} \mathrm{C}\right)$ than at low temperatures $\left(25^{\circ} \mathrm{C}\right)$. On the contrary, the survival rate of divided parts increased as water temperature decreased. The wound-healing period lasted longer at high temperatures than at low temperatures, so they concluded that the dividing rate increased with an increasing water temperature, while the survival rate of divided parts and the wound-healing period increased when the temperature decreased. This fenomenon might also happened in this experiment, since the temperature of seawater of Karimunjawa waters were $25-32^{\circ} \mathrm{C}$.

Regeneration period of different part of the body varied with fission plane (Table 1). The two fission plane give regeration period (52-86 days) faster than three fission plane (68-125 days). Regeneration is in fact a distinct type of developmental process typically occurring in echinoderm: it can involve limited processes of cell turnover and tissue repair, replacement of lost parts or organs, cast off following self-induced or traumatic mutilations, and even complete regrowth of whole individuals from body fragments (thus contributing to typical asexual reproductive processes). Carnevali (2006) showed that in Holothuroids, regeration mechanisms consists of epimorphic-like regeneration with presumptive contribution of undifferentiated cells, pseudoblastema formation and nerve-dependent regeneration. He also proposed that In holothurians the regenerative potential can differ a lot between different groups (Dendrochirota, Aspidochirota, Apoda) and also vary with the age of the individuals.

Following fission process, there are two regeneration of sea cucumber, i.e. regeneration of internal organs and body growth. Although in present work, the observation only carried out for body growth, the internal organt development was discussed based on Dolmatov (2014). The set of organs remaining in the fragments after fission, in two and three fission plane, the anterior fragment retains the aquapharyngeal complex (AC), gonads, and one or two segments of the gut (Conand et al., 1998; Tipper et al., 2002; Dolmatov et al., 2012; Dolmatov, 2014). The posterior fragment of these animals contains the cloaca, a larger portion of the gut, the respiratory trees, and, if any, cuvierian tubules and gonad. In the middle fragments (Middle 1 in two fission plane and Middle 1 and Middle 2 in three fission plane) may retains small portion of intestine, gut and resporatory trees. According to Dulmatov (2014), in the anterior fragment, regeneration after fission begins with partial atrophy of the damaged first descending portion of the intestine, simultaneously the wound at the posterior end is repaired. The intestine then begins to grow backward, down the mesentery, simultaneously, the cloaca develops at the posterior end of the anterior fragment in which intestine grows joint into the cloaca, and the integrity of the digestive systemis restored. At this point, sea cucumber restore the terminal regions of the longitudinalmuscle bands (LMB), it's ends become thinner and grow toward the cloaca. After the intestine and cloaca merge, the primordia of the respiratory trees appear on the dorsal side of the cloaca (Dulmatov, 2014). According to Garcia-Arraras et al. (1998; 2001), Garcia-Arraras and Greenberg (2001) and Dolmatov $(1992 ; 1996)$ the new digestive tube develops from the mesentherial lamina, which anchored the original gut to the body wall. On the basis of indirect evidence, the overall process is considered to be a nerve-dependent regeneration. At the posterior end of anterior fragment, a small outgrowth emerges and subsequently becomes longer, thus forming the posterior region of the animal. Respiratory trees develop with the growth of the posterior end.

The main event in the posterior fragment following fission is the regeneration of aquapharyngeal complex (AC) (Dolmatov, 2014) include radial nerve cords, radial water-vascular canals, nerve ring and circular water-vascular canal as well as anterior region of the intestine. The intestine becomes thinner and begins growing forward up the mesentery, into the $A C$ and the integrity of the digestive system is restored. Then the animal begins to grow. At the anterior end, a small outgrowth emerges and gradually grows longer, thus forming the anterior region of the animal. integrity of the digestive system is restored. Respiratory trees in the anterior fragment develop through the transformation of the dorsal wall of the anterior region of the cloaca (Dolmatov and Ginanova 2009; Dolmatov et al., 2011). According to Dolmatov and Ginanova (2001) muscle regeneration process appears to be due to the coelomic epithelial cells 
which apparently dedifferentiate, migrate and invade the muscle bands where they differentiate into muscle bundle rudiments, finally giving rise to new muscle cells.

Based on discussion of Dolmatov (2014) the formation of internal organs of S. herrmanni before the growth of an external region of two fission plane occurs for approximately 40 days (Table 1). Consequently, the sea cucumber have a small outgrowth at the anterior and posterior end after fission occurred over almost two months. This results were shorter than other holothurians which may range from 1.5 to 3 months (Reichenbach and Holloway , 1995; Purwati et al., 2009; Dolmatov et al., 2012). In C. schmeltzii, the formation of internal organs without the growth of an external region occurs for approximately 30 days (Dolmatov et al. 2012). For three fission plane, the posterior and anterior end of anterior and posterior fragment was recover in almost similar period of time, but regeration time is shorter in the posterior end of anterior fragment. The regeration period of middle fragment showed very slow, i.e. more than 75 days.

Growth of the body begins when the internal organs are formed. Initial signs of regeneration at the fission site, the dermis is depigmented and a protuberance forms. As carried out in present work, assessments of fission and regeneration rates are typically based on the externalmorphology of the animals, particularly the presence of the growing anterior or posterior end of the body. Table 2 and Table 3 showed that average growth of anterior and posterior fragment were 24,5 and $29 \mathrm{~mm}$ for two fission plane and 11,5 and 2,4 $\mathrm{mm}$ for three fission plane. The middle fragment (M1 and M2) both fission plane was able to grow but very low, i.e range of 1,85-13,1 mm. In anterior end of the middle 1 of two fission plane was longer than posterior end. In the contrary, anterior and posterior end of $\mathrm{M} 1$ is longer than M2 of three fission plane. The growth duration of the body varies broadly and apparently depends on the species (Dolmatov, 2014). The same related experiment still scarse. In C.schmeltzii individuals showed 2-3 mm long outgrowth (10$15 \%$ of body length) formed within 25 days when the animals were maintained under artificial conditions after fission (Dolmatov, 2014). In S. chloronotus, growth of the external region to normal size required up to one month (Conand et al., 2002). According to Jaquemet et al. (1999) the regeneration of $H$. atra after fission took six months.

The survival rate of individu after fission with two fission plane were generally greater $(70-80 \%)$ than those fission with three fission plane (30-60\%) (Tabel 2). Sea cucumber survivorship also indicate that the posterior part (Table 2 and Table 3) have a higher percentage than the other part (middle and anterior). These results are similar to work done by Reichenbach et al., (1996) where S. variegatus (now S. herrmanni) on the posterior part has a higher value than the anterior part of the regeneration stage. The same result also showed the fission stimulation of 10 species of sea cucumber by Hartati et al. (2009), S. horrens dan S. vastus (Hermawan et al., 2012), H. impatiens (Nugroho et al., 2012), S. herrmanni (Hartati et al., 2013; 2015a; b), H. edulis and H. leucospilota (Karim et al. (2013); and H. atra (Muttaqin et al., 2013).

The weight of sea cucumber may affect the survival rate of fission result. The average weight of sea cucumber tested in present work was $350 \mathrm{~g}$, the two fission plane gave better result than three fission plane. . The studies of Lambeth (2000) showed that small (median weight $600 \mathrm{~g}$ ) and medium size (median weight 1,300 g) S. variegatus (now called S. herrmanni) were able to regenerate both anterior and posterior parts (with 100 per cent survival) into whole animals in around 40-80 days.

Tabel 1. Wound recovery and regeneration period (days) of anterior, middle and posterior individu S. herrmanni resulted from two and three fission plane

\begin{tabular}{ccccc}
\hline Treatment & Individu & $\begin{array}{c}\text { Wound } \\
\text { location }\end{array}$ & $\begin{array}{c}\text { Wound recovery period } \\
\text { day - (average) }\end{array}$ & $\begin{array}{c}\text { Regeneration Period started at } \\
\text { day - (average) }\end{array}$ \\
\hline \multirow{2}{*}{$\begin{array}{c}\text { 2 Fission } \\
\text { plane }\end{array}$} & Anterior & Anterior & $43-57(50)$ & $52-67(59,5)$ \\
& Middle 1 & Anterior Middle1 & $57-79(68)$ & $67-86(76,5)$ \\
& Posterior & Posterior Middle1 & $54-67(60,5)$ & $54-74(69)$ \\
& Anterior & Posterior & $42-54(48)$ & $68-89(78,5)$ \\
& Middle 1 & Anterior & $58-78(68)$ & $76-95(85,5)$ \\
3 Fission & Posterior Middle1 & $62-88(75)$ & $75-108(91,5)$ \\
plane & Middle 2 & Anterior Middle2 & $67-92(79,5)$ & $85-120(102,5)$ \\
& & Posterior Middle2 & $73-94(83,5)$ & $90-125(107,5)$ \\
& Posterior & Posterior & $74-94(84)$ & $78-90(84)$ \\
\hline
\end{tabular}


Tabel 2. The growth (length range and average, $\mathrm{mm}$ ) of body part $\mathrm{S}$. herrmanni after fussion with two fission plane and their survival rate $(\%)$ in $16^{\text {th }}$ week.

\begin{tabular}{ccccc}
\hline Week & Anterior & Anterior Middle 1 & Posterior Middle 1 & Posterior \\
\hline 0 & 0 & 0 & 0 & 0 \\
2 & 0 & 0 & 0 & 0 \\
4 & 0 & 0 & 0 & 0 \\
6 & $0-3(1,5)$ & $0-2(2)$ & 0 & $0-2(1)$ \\
8 & $3-8(5,5)$ & $1-4(2,1)$ & $0-3(1,5)$ & $3-7(5)$ \\
10 & $5-13(9)$ & $3-7(4,4)$ & $0,7-3,5(2,1)$ & $6,5-16(11,3)$ \\
12 & $8-19(13,5)$ & $5-8(6,7)$ & $1,1-3,6(2,35)$ & $9-25(17)$ \\
14 & $11-26(18,5)$ & $7-12(9,75)$ & $1,3-3,7(2,5)$ & $14-34(24)$ \\
16 & $16-33(24,5)$ & $9-18(13,1)$ & $1,6-3,8(2,7)$ & $19-39(29)$ \\
\hline Survival Rate (\%) & 70 & \multicolumn{3}{c}{70} \\
\hline
\end{tabular}

Tabel 3. The growth (length range and average, $\mathrm{mm}$ ) of body part S. herrmanni after fussion with three fission plane and their survival rate $(\%)$ in $16^{\text {th }}$ week.

\begin{tabular}{ccccccc}
\hline Week & Anterior & Anterior Middle & $\begin{array}{c}\text { Posterior Middle } \\
\text { Anterior Middle }\end{array}$ & $\begin{array}{c}\text { Posterior Middle } \\
2\end{array}$ & Posterior \\
\hline 0 & 0 & 0 & 0 & 0 & 0 & 0 \\
2 & 0 & 0 & 0 & 0 & 0 & 0 \\
4 & 0 & 0 & 0 & 0 & 0 & 0 \\
6 & 0 & 0 & 0 & 0 & 0 & 0 \\
8 & $0-2(1)$ & 0 & 0 & 0 & 0 & $0-0,4(0,2)$ \\
10 & $3-5,5(4,3)$ & $0-2(1)$ & $0-1(0,5)$ & $0-0,1(0,05)$ & 0 & $0,2-1,4(0,8)$ \\
12 & $7-9(8)$ & $1-3(2)$ & $1-2(1,5)$ & $0,6-1,4(1)$ & $1-1,6(1,3)$ & $0,8-2,4(1,6)$ \\
14 & $8-13(10,5)$ & $2-3,3(2,65)$ & $1-3,2(2,1)$ & $1,1-2,7(1,9)$ & $1,1-2,1(1,6)$ & $1,1-2,7(1,9)$ \\
16 & $9-14(11,5)$ & $2-3,5(2,75)$ & $2-3,4(2,7)$ & $1,4-2,9(2,15)$ & $1,4-2,3(1,85)$ & $1,4-3,4(2,4)$ \\
\hline Survival Rate $(\%)$ & 50 & \multicolumn{5}{c}{30} \\
\hline
\end{tabular}

The shortest regeneration time was for the posterior parts of the smallest weight class of S. variegatus. In the contrary, adult $S$. variegatus with a median wet weight of $3,650 \mathrm{~g}$ were able to regenerate only the

Transverse cutting experiments have shown that not all holothurians can restore both body fragments (Reichenbach and Holloway , 1995; Reichenbach et al., 1996; Dolmatov and Mashanov, 2007; 2626, Dolmatov et al. 2012). For example, both anterior and posterior fragments of Actinopyga mauritiana die after constricting of the body with a rubber band (Reichenbach and Holloway, 1995). In Holothuria fuscogilva, A. miliaris, and Stichopus variegatus only the posterior parts can regenerate into whole animals (Reichenbach and Holloway, 1995). On the other hand smaller (younger) individuals of $A$. mauritiana, $H$. fuscogilva, and $S$. variegatus have higher survivorship and shorter regeneration time relative to adults (Reichenbach et posterior part into a whole animal, in around 100 days, with zero per cent survival of the anterior parts and 80 per cent survival of the posterior parts.

al., 1996). After transverse cutting both fragments of Holothuria pervicax, H. impatiens, and Massinium magnum die (Dolmatov et al. 2012; Dolmatov, 2014). Only posterior parts of Apostichopus japonicus, Holothuria scabra, Ohshimella ehrenbergi, and Colochirus quadrangularis can regenerate lost anterior structures after such operation (Dolmatov and Mashanov, 2007; Dolmatov et al. 2012; Dolmatov, 2014)

\section{Conclusion}

The Wound recovery and regeneration period (days) of anterior, middle and posterior individu S. herrmanni resulted from two and three fission plane 
were varied but the two fission plane the anterior individu recover for longer period than posterior part and the wound recover process in both end for thee fission plane was same. Average growth of anterior and posterior fragment were longer for two fission plane than three fission plane. The middle fragment (M1 and M2) both fission plane was able to grow but very low.

\section{Acknowledgement}

The author would like to thank the Director of Research and Community Service, Directorate General for Research and Development Strengthening of the Ministry of Research, Technology and Higher Education who funded this research through a Letter of Agreement Assignment Implementation Research Number : 002/SP2H/LT/ DRPM/II/ 2016 of $17^{\text {th }}$ February 2016.

\section{References}

Carnevali, M.C., 2006. Regeneration in Echinoderms: repair, regrowth, cloning. Invertebrate Survival J. 3:64-76.

Conand, C., Morel, C. \& Mussard, R., 1997. A new study of asexual reproduction in holothurians: Fission in Holothuria leucospilota populations on Reunion Island in the Indian Ocean. SPC Beche-de-mer Info. Bull. 9:5-11.

Conand, C., Armand, J., Dijoux, N. \& Garryer, J., 1998. Fission in a population of Stichopus chloronotus on Reunion Island, Indian Ocean. SPC Beche-de-Mer Info. Bull. 10:15-23.

Conand, C., Uthicke, S. \& Hoareau, T. 2002. Sexual and asexual reproduction of the holothurian Stichopus chloronotus (Echinodermata): a comparison between La R'eunion (Indian Ocean) and East Australia (Pacific Ocean). Invert. Reprod. Dev. 41:235-242. doi : 10. $1080 / 07924259.2002 .9652756$

Dolmatov, I.Y. 1992. Regeneration of the aquapharingeal complex in the holothurian Eupenctacta fraudatrix (Holothuroidea, Dendrochirota). In: Taban CH, Boilly B (eds) Keys for Dendrochirota) after artificial transverse bisection. Russ. J. Mar. Biol. 39: 143-151.

Dolmatov, I.Y. 1996. Asexual reproduction, evisceration and regeneration in holothurians. Russ. J. Dev. Biol. 27:211-219.
Dolmatov, I.Y., 2014. Asexual Reproduction in Holothurians. The Scientific World Journal, 2014. doi : 10.1155/2014/ 527234

Dolmatov, I.Y. \& Ginanova, T.T. 2001. Muscle regeneration in holothurians. Microsc Res Tech. 55(6):452-63.

Dolmatov, I.Y. \& Mashanov, V.S., 2007. Regeneratsiya $u$ goloturiy (Regeneration in Holothurians). Vladivostok: Dal'nauka..

Dolmatov, I.Y. \& Ginanova, T.T., 2009. Postautotomy regeneration of respiratory trees in the holothurian Apostichopus japonicus (Holothuroidea, Aspidochirotida). Cell Tissue Res. 336(1):41-58. doi: 10.1007/s00441-0090761-6

Dolmatov, I.Y., Eliseikina, M.G., Ginanova, T.T., Lamash, N.E., Korchagin, V.P. \& Bulgakov, A.A., 1996. Muscle regeneration in the holothurian Stichopus japonicus. Roux's Arch. Dev. Biol. 205(7-8):486-493. doi: 10.1007/BF00377230

Dolmatov, I.Y., Frolova, L.T., Zakharova, E.A. \& Ginanova, T.T., 2011. Development of respiratory trees in the holothurian Apostichopus japonicus (Aspidochirotida: Holothuroidea). Cell Tissue Res. 346(3):327338. doi: 10.1007/s00441-011-1280-9.

Dolmatov, I.Y., Khang, N.A. \& Kamenev, Y.O., 2012. Asexual reproduction, evisceration, and regeneration in holothurians (Holothuroidea) from Nha Trang Bay of the South China Sea. Russ. J. Mar. Biol. 38(3):243-252. doi: 10.1134/S1063074012030042

Garcia-Arraras, J.E., \& Greenberg, M.J. 2001. Visceral regeneration in holothurians. Micr. Res. Tech. 55: 438-451.

García-Arrarás, J.E., Estrada-Rodgers, L., Santiago, R., Torres, I.I., Díaz-Miranda, L. \& Torres-Avillán, I., 1998. Cellular mechanisms of intestine regeneration in the sea cucumber, Holothuria glaberrima Selenka (Holothuroidea: Echinodermata). J. Exp. Zool. 281(4):288-304. doi: 10.1002/(SICI)1097-010X (19980701)28 $1: 4$

Hartati, R., Widianingsih \& Purwati, P. 2009. Fission Reproduction Sebagai Teknik Perbanyakan individu Dalam Konservasi Teripang Holothuria : Echinodermata). Laporan Penelitian Hibah Penelitian Strategis Nasional Batch II. Lembaga Penelitian Universitas Diponegoro. 35 hal. 
Hartati, R., Widianingsih \& Purwati, P., 2013. Reproduksi Fission dari Dua Species Teripang Famili Stichopudidae (Holothuria: Echinodermata. ILMU KELAUTAN: Indonesian Journal of Marine Sciences, 18(2):12-118. doi: 10.14710/ik.ijms.18.2.112-118

Hartati, R., Widianingsih \& Endrawati, H. 2015 a. Recovery perfomance Teripang Trill, Stichopus hermanni (Stichopodidae : Echinodermata) setelah fission. Prosiding Seminar Nasional Tahunan Hasil Penelitian Perikanan dan Kelautan XII. Jogjakarta, 8 Agustus 2015. Universitas Gajahmada. Jilid II. Manajemen Sumberdaya Perikanan. UGM. Jogjakarta.

Hartati, R. Widianingsih \& Rudianto, A. 2015b. Fission as a prosperous attempt for Sea cucumber Pearsonothuria graeffei and Bohadschia similis (Holothuria : Echinoderm) Conservation. The $2^{\text {nd }}$ International Symposium on Aquatic Products Processing and Health September 13-15, 2015 Diponegoro University, Semarang, Indonesia.

Hermawan, Widianingsih \& Hartati, R. 2012. Stimulasi Reproduksi Aseksual Pada Stichopus horrens dan Stichopus vastus di Perairan Pulau Karimunjawa, Kabupaten Jepara. J. Mar. Res. 1(2):118-124

Jaquemet, S., Rousset, V. \& Conand, C. 1999. Asexual reproduction parameters and the influence of fission on a Holothuria atra sea cucumber population from a fringing reef on Reunion Island. Russ. J. Mar. Biol. 38(3):243252.

Karim, R. A., Hartati, R \& Widianingsih. 2013. Kemampuan fission teripang Holothuria edulis dan Holothuria leucospilota (Holothuridae) ukuran yang berbeda di Kepulauan Karimunjawa. J. Mar. Res. 2(1):154-160

Kohtsuka, K., Arai, S., \& Uchimura, M., 2005. Observation of asexual reproduction by natural fission of Stichopus horrens Selenka in Okinawa Island, Japan. SPC Beche-de-mer Info. Bull. 22:23-24.

Lambeth, L. 2000. The subsistence use of Stichopus variegatus (now $S$. herrmanni) in the Pacific Islands. SPC Beche-de-Mer Info. Bull. 13:18-21

Laxminarayana, A. 2006. Asexual reproduction by induced transverse fission in the sea cucumbers Bohadschia marmorata and Holothuria atra. SPC Beche-de-Mer Info. Bull. 23: 35-37.
Muttaqin, A.R., Hartati, R \& Kushartanto, E.W. 2013. Stimulasi fission pada reproduksi aseksual teripang Holothuria atra. J. Mar. Res. 2(1):96102

Nugroho, D., Hartati, R. \& Suprijanto, J. 2012. Stimulasi Fission Reproduksi Aseksual Teripang Holothuria atra dan Teripang Holothuria impatiens. J. Mar. Res. 1(2):161-166

Purwati, P. \& Dwiono, S.A.P. 2005. Fission inducement in Indonesian holothurians. SPC Beche-de-mer Info. Bull., 22:11-15

Purwati, P. \& Dwiono, S.A.P. 2007. Experiment on fission stimulatyion of Holothuria atra (Holothuroidea, Echinodemata): Changing in Body Weight and Morphology. Marine Research in Indonesia 32(1):1-6

Purwati, P., Dwiono, S.A., Indriana, L.F. \& Fahmi, V., 2009. Shifting the natural fission plane of Holothuria atra (Aspidochirotida, Holothuroidea, Echinodermata). SPC Beche-de-Mer Info. Bull. 29:16-19

Razek, F.A., Rahman, S.A., Mona, M.H., El-Gamal, M.M. \& Moussa, R.M., 2007. An observation on the effect of environmental conditions on induced fission of the Mediterranean sand sea cucumber, Holothuria arenicola (Semper, 1868) in Egypt. Beche-de-Mer Information Bulletin, 24:45-48.

Reichenbach, N., Y. Nishar, \& A. Saeed. 1996. Species and sizerelated trends in asexual propagation of commercially important species of tropical sea cucumbers (Holothuroidea). J. the World Aquacult. Soc. 27(4):475-482.

Reichenbach, N. \& S. Holloway. 1995. Potential for asexual propagation of several commercially important species of tropical sea cucumber (Echinodermata). J. World Aquacult. Soc. 26(3): 272-278.

Tipper, J.P., G. Lyons-Levy, M. A. L. Atkinson, \& J. A. Trotter. 2002. Purification, characterization and cloning of tensilin, the collagen-fibril binding and tissue-stiffening factor from Cucumaria frondosa dermis. Matrix Biology 21(8): 625635.

Uthicke,S. 2001.Influence of asexual reproduction on the structure and dynamics of Holothuria (Halodeima) atra and Stichopus chloronotus populations of the Great Barrier Reef..Mar. and Freshw. Res.,52(2): 205-215 